\title{
ONE-STEP PURIFICATION AND CHARACTERIZATION OF CELLULASE-FREE XYLANASE PRODUCED BY ALKALOPHILIC BACILLUS SUBTILIS ASH
}

\author{
Ashwani Sanghi ${ }^{1}$; Neelam Garg ${ }^{2}$; V.K.Gupta ${ }^{1 *}$; Ashwani Mittal ${ }^{1}$; R.C.Kuhad ${ }^{3}$ \\ ${ }^{1}$ Department of Biochemistry, Kurukshetra University, Kurukshetra, India; ${ }^{2}$ Department of Microbiology, Kurukshetra University, \\ Kurukshetra, India; ${ }^{3}$ Department of Microbiology, University of Delhi South Campus, New Delhi, India \\ Submitted: September 30, 2008; Returned to authors for corrections: February 11, 2009; Approved: September 23, 2009.
}

\begin{abstract}
The present study describes the one-step purification and characterization of an extracellular cellulase-free xylanase from a newly isolated alkalophilic and moderately thermophilic strain of Bacillus subtilis ASH. Xylanase was purified to homogeneity by 10.5 -fold with $\sim 43 \%$ recovery using ion-exchange chromatography through CM-Sephadex C-50. The purified enzyme revealed a single band on SDS-PAGE gel with a molecular mass of $23 \mathrm{kDa}$. It showed an optimum $\mathrm{pH}$ at 7.0 and was stable over the $\mathrm{pH}$ range 6.0-9.0. The optimum temperature for enzyme activity was $55^{\circ} \mathrm{C}$. The purified xylanase did not lose any activity up to $45^{\circ} \mathrm{C}$, however, it retained $80 \%$ and $51 \%$ of its activity after pre-incubation at $55^{\circ} \mathrm{C}$ and 60 ${ }^{\circ} \mathrm{C}$, respectively. The enzyme obeyed Michaelis-Menton kinetics towards birch wood xylan with apparent $\mathrm{K}_{\mathrm{m}} 3.33 \mathrm{mg} / \mathrm{ml}$ and $\mathrm{V}_{\max } 100 \mathrm{IU} / \mathrm{ml}$. The enzyme was strongly inhibited by $\mathrm{Hg}^{2+}$ and $\mathrm{Cu}^{2+}$ while enhanced by $\mathrm{Co}^{2+}$ and $\mathrm{Mn}^{2+}$. The purified enzyme could be stored at $4{ }^{\circ} \mathrm{C}$ for six weeks without any loss of catalytic activity. The faster and economical purification of the cellulase-free xylanase from $B$. subtilis ASH by onestep procedure together with its appreciable stability at high temperature and alkaline $\mathrm{pH}$ makes it potentially effective for industrial applications.
\end{abstract}

Key words: Alkalophilic, Bacillus subtilis, Purification, Xylanase

\section{INTRODUCTION}

Xylanase (endo-1, 4- $\beta$-D-xylanohydrolase; EC 3.2.1.8) is a hydrolytic enzyme involved in depolymerization of xylan, the major renewable hemicellulosic polysaccharide of plant cell wall. It is produced by bacteria $(11,19,37,41)$, fungi $(29,34$, 41), actinomycetes (33) and yeast (26). Recently, interest in xylanase has markedly increased due its wide variety of biotechnological applications such as pre-bleaching of pulp, improving the digestibility of animal feed stocks, modification of cereal-based stuffs, bioconversion of lignocellulosic material and agro-wastes to fermentable products, clarification of fruit juices and degumming of plant fibers $(15,21,44)$ etc. Cellulase-free xylanases active at high temperature and $\mathrm{pH}$ are gaining importance in pulp and paper industry as they reduce the need for toxic chlorinated compounds making the bleaching process environment-friendly $(40,43)$.

The industrial application of xylanase may be limited by its high cost of production. The use of cost-effective agroresidues as substrates in solid state fermentation may reduce 
the cost of enzyme production substantially (37). Solid state fermentation offers several advantages over submerged fermentation including simplicity of media, greater product yield, easier scale up of process, economy of space, no complex machinery, equipment and control systems etc $(2,14)$. In order to investigate the biotechnological applications of this enzyme, it would be desirable to purify and characterize it. Presently, purification and characterization costs are becoming important issues in modern biotechnology as the industry matures and competitive products reach the market. Although, purification of microbial xylanase has been reported by several investigators using a combination of two or more standard enzyme purification techniques yet it would be advantageous to develop a one-step purification procedure so as to reduce the enzyme cost. In this study, we report a single step purification and characterization of an extracellular cellulase-free xylanase from an alkalophilic and moderately thermophilic strain of Bacillus subtilis ASH 7414 isolated from soil.

\section{MATERIALS AND METHODS}

\section{Microbial strain and its growth conditions}

The xylanase-producing bacterial strain used in this study was isolated from soil sample collected locally from Kurukshetra, India, by using enrichment technique with wheat bran as a source of carbon. The organism was identified as Bacillus subtilis ASH 7414 on the basis of its morphological, physiological and biochemical characteristics by the Institute of Microbial Technology (IMTECH). It was assigned the accession number MTCC 7414. The culture was maintained at $4{ }^{\circ} \mathrm{C}$ on nutrient agar medium (in g/l: peptone, 5.0; beef extract, $3.0 ; \mathrm{NaCl}, 5.0 ; \mathrm{pH} 7.0 ; 2 \%$ agar).

\section{Xylanase production and extraction}

Xylanase was produced by B. subtilis ASH 7414 in solidstate fermentation. Erlenmeyer flasks each containing $10 \mathrm{~g}$ wheat bran and $25 \mathrm{ml}$ mineral salt solution (in $\mathrm{g} / \mathrm{l}$ : $\left.\mathrm{MgSO}_{4} .7 \mathrm{H}_{2} \mathrm{O}, 0.2 ; \mathrm{K}_{2} \mathrm{HPO}_{4}, 0.4 ; \mathrm{pH} 7.0\right)$ were autoclaved at $1.05 \mathrm{~kg} / \mathrm{cm}^{2}$ for $45 \mathrm{~min}$ and cooled. After inoculation with $10 \%$ (v/w) of $18 \mathrm{~h}$ old inoculum, the flasks were incubated at $37^{\circ} \mathrm{C}$ for $72 \mathrm{~h}$. The flasks were gently tapped intermittently to mix the contents. The incubator was humidified by keeping a tray containing sterile distilled water.

Xylanase was extracted from the above bacterial bran with $100 \mathrm{ml}$ of sodium phosphate buffer $(0.05 \mathrm{M}, \mathrm{pH} 7.0)$ by gently squeezing through a wet muslin cloth followed by centrifugation at $10,000 \mathrm{x} \mathrm{g}$ for $30 \mathrm{~min}$ at $4^{\circ} \mathrm{C}$. The clear supernatant (crude extract) was used for xylanase purification.

\section{Xylanase assay}

Xylanase activity was assayed by measuring the amount of reducing sugars liberated from birchwood xylan using 3, 5dinitrosalicylic acid (28). The reaction mixture $(1.0 \mathrm{ml})$ containing $0.5 \mathrm{ml}$ of $1 \%$ birchwood xylan (prepared in $0.05 \mathrm{M}$ sodium phosphate buffer, $\mathrm{pH} 7.0$ ) as substrate, $0.02 \mathrm{ml}$ of appropriately diluted enzyme extract and $0.48 \mathrm{ml}$ of sodium phosphate buffer $(0.05 \mathrm{M}, \mathrm{pH} 7.0)$ was incubated at $55^{\circ} \mathrm{C}$ for 5 min and then the reaction was terminated by adding $3.0 \mathrm{ml}$ of 3, 5-dinitrosalicylic acid reagent. A control was run simultaneously which contained all the reagents but the reaction was terminated prior to the addition of enzyme extract. The test tubes were placed in a boiling water bath for $10 \mathrm{~min}$. After cooling to room temperature, the absorbance of the resulting red color was measured against the control at $540 \mathrm{~nm}$ using a double beam spectrophotometer (Systronics 2202, India). One unit of xylanase activity was defined as the amount of enzyme catalyzing the release of $1 \mu \mathrm{mol} / \mathrm{min}$ of reducing sugars equivalent to xylose under the specified assay conditions. Cellulase activity was assayed as above, using low viscosity carboxymethylcellulose $(1 \%)$ in place of xylan as substrate. All the experiments were carried out independently in triplicate and the results presented are mean of the three values.

\section{Protein estimation}

Protein was estimated by the Lowry's method using bovine serum albumin as standard (27). The protein content of the chromatographic fractions was measured by monitoring the optical density at $280 \mathrm{~nm}$ in a double beam spectrophotometer. 


\section{Purification of xylanase}

The crude enzyme extract was chromatographed on CMSephadex C-50 column $(20 \mathrm{~cm} \times 2.0 \mathrm{~cm})$, pre-equilibrated with $50 \mathrm{mM}$ sodium phosphate buffer ( $\mathrm{pH}$ 6.0). The column was run at a flow rate of $40 \mathrm{ml} / \mathrm{h}$. The bound proteins were eluted using a continuous gradient of $0-1.0 \mathrm{M} \mathrm{NaCl}$. Fractions of $5 \mathrm{ml}$ each were collected and analyzed for protein content and xylanase activity. The fractions containing enzyme activity were pooled and concentrated using Amicon ultrafiltration cell membrane (10 kDa cut off).

\section{Checking of enzyme homogeneity}

The purity of the enzyme was checked by performing $12 \%$ SDS-PAGE as described by Laemmli (22). Protein bands were visualized by staining with coomassie brilliant blue R-250. A reverse phase C-18 column $(4.6$ x $250 \mathrm{~mm}$; E. Merck, Germany) of High Performance Liquid Chromatography (HPLC System 600 Waters, Waters Corporation, Massachusetts, USA) was also employed to test the enzyme purity. The sample components were separated using the solvent system acetonitrile-water (70:30) at a flow rate of 0.5 $\mathrm{ml} / \mathrm{min}$. A highly sensitive photo-diode array (PDA) detector (996 Waters) was set to read the absorbance at $280 \mathrm{~nm}$.

\section{Characterization of the purified enzyme}

\section{Molecular weight determination}

Molecular weight (MW) of the purified xylanase was estimated by SDS-PAGE and gel filtration. SDS-PAGE was performed as described above using molecular weight markers viz. lysozyme (14.3 kDa), trypsinogen (24 kDa), pepsin (34.7 $\mathrm{kDa})$, ovalbumin $(46 \mathrm{kDa})$ and $\mathrm{BSA}(66 \mathrm{kDa})$. Gel filtration chromatography was performed on a Sephadex G-100 column (90 $\mathrm{cm} \times 0.8 \mathrm{~cm}$ ), pre-equilibrated with $50 \mathrm{mM}$ sodium phosphate buffer, pH 6.0. The purified enzyme was loaded onto top of this column, which was run at $15 \mathrm{ml} / \mathrm{h}$ and fractions of $3 \mathrm{ml}$ each were collected. A mixture of gel filtration protein molecular weight markers viz. carbonic anhydrase (29 kDa), BSA (66 kDa), alcohol dehydrogenase $(150 \mathrm{kDa})$ and $\beta$ amylase (205 kDa) was also separated on the same column under identical conditions and their elution volumes were determined. A standard graph was then plotted between $\mathrm{V}_{\mathrm{e}} / \mathrm{V}_{\mathrm{o}}$ on $\mathrm{x}$-axis and $\log \mathrm{MW}$ on $\mathrm{y}$-axis for calculation of molecular weight of the purified xylanase.

\section{Determination of $K_{m}$ and $V_{\text {max }}$}

Initial reaction rate of birchwood xylan hydrolysis was determined by varying its concentration in the range of 1 to 15 $\mathrm{mg} / \mathrm{ml}$ in standard xylanase assay and the double reciprocal plot was drawn. The kinetic parameters $\mathrm{K}_{\mathrm{m}}$ and $\mathrm{V}_{\max }$ were estimated from this plot (25).

\section{Effect of temperature on activity and stability of xylanase}

The optimum temperature for the purified xylanase activity was determined by assaying the enzyme activity at different temperatures ranging from $30-65{ }^{\circ} \mathrm{C}$. To investigate the thermal stability of the purified xylanase, an aliquot of the enzyme was pre-incubated at different temperatures $\left(30-60{ }^{\circ} \mathrm{C}\right)$ for $10 \mathrm{~min}$ at $\mathrm{pH}$ 7.0, quickly chilled and assayed for its residual activity at $55^{\circ} \mathrm{C}$.

\section{Effect of pH on activity and stability of xylanase}

The effect of $\mathrm{pH}$ on xylanase activity was studied by carrying out the enzyme assay using buffers of different $\mathrm{pH}$ ranging from 4.0 to 10.0. Three different buffers (each at $0.05 \mathrm{M})$ viz. citrate buffer $(\mathrm{pH} 4.0-6.0)$, phosphate buffer $(\mathrm{pH}$ 6.0-8.0) and Tris- $\mathrm{HCl}(\mathrm{pH} 8.0-10.0)$ were used for this study. To test the pH stability of the enzyme, an aliquot of the purified enzyme was pre-incubated with the above mentioned buffers of different $\mathrm{pH}(4.0-9.0)$ for $10 \mathrm{~min}$ at room temperature followed by measurement of xylanase activity using sodium phosphate buffer $(0.05 \mathrm{M}, \mathrm{pH} 7.0)$. The residual activity $(\%)$ at each $\mathrm{pH}$ was calculated.

\section{Effect of metal ions}

The purified enzyme was incubated with various metal salts viz. $\mathrm{ZnCl}_{2}, \mathrm{CaCl}_{2}, \mathrm{HgCl}_{2}, \mathrm{NaCl}, \mathrm{KCl}, \mathrm{FeCl}_{3}, \mathrm{MgCl}_{2}$, $\mathrm{CoCl}_{2}, \mathrm{CdCl}_{2}, \mathrm{NiCl}_{2}, \mathrm{CuCl}_{2}$ and $\mathrm{MnCl}_{2}$ at a final concentration of $1 \mathrm{mM}$ for $5 \mathrm{~min}$ at room temperature and then xylanase 
activity was assayed. The residual activity (\%) was then calculated.

\section{Determination of shelf life}

The shelf life of the purified enzyme was determined by keeping it in a refrigerator $\left(4^{\circ} \mathrm{C}\right)$ and at room temperature. Enzyme samples were withdrawn at different intervals up to 10 weeks and the residual xylanase activity was determined.

\section{RESULTS AND DISCUSSION}

\section{Microbial strain and its growth conditions}

Bacillus subtilis ASH is an alkalophile being capable of growing at $\mathrm{pH}$ values up to 11.0. It is a moderate thermophile with minimum, optimum and maximum temperature for growth at 15,37 and $55^{\circ} \mathrm{C}$, respectively (37).

\section{Enzyme activity}

The bacterium produced high levels of xylanase $(8,964$ U/g dry wheat bran) in solid state fermentation under optimized conditions. The enzyme was cellulase-free as the crude extract was devoid of cellulase activity. Lignocellulosic materials have been used earlier by various researchers for production of xylanase but with lower activity $(3,9,12)$.

\section{Purification of xylanase}

Xylanase produced by $B$. subtilis ASH in solid state fermentation on wheat bran was purified to apparent homogeneity by a single step chromatographic procedure. After loading the crude extract onto the column of CMSephadex C-50, the enzyme eluted as a single peak in bound fractions at $0.675 \mathrm{M} \mathrm{NaCl}$ as shown in Fig. 1. The fractions containing enzyme activity were pooled and concentrated using Amicon ultrafiltration cell membrane (10 kDa cut off). The purity of the purified enzyme was checked by SDS-PAGE and reverse phase HPLC on $\mathrm{C}-18$ column. The purified enzyme showed a single band in SDS-PAGE gel indicating that it was homogeneous (Fig. 2). HPLC chromatogram of the purified enzyme also revealed a single peak at a retention time of 2.513 min confirming that it was a pure preparation (Fig. 3). The yield of the purified xylanase was $43.05 \%$ with a specific activity of $1275.5 \mathrm{IU} / \mathrm{mg}$ and an overall purification fold of 10.5 (Table 1).

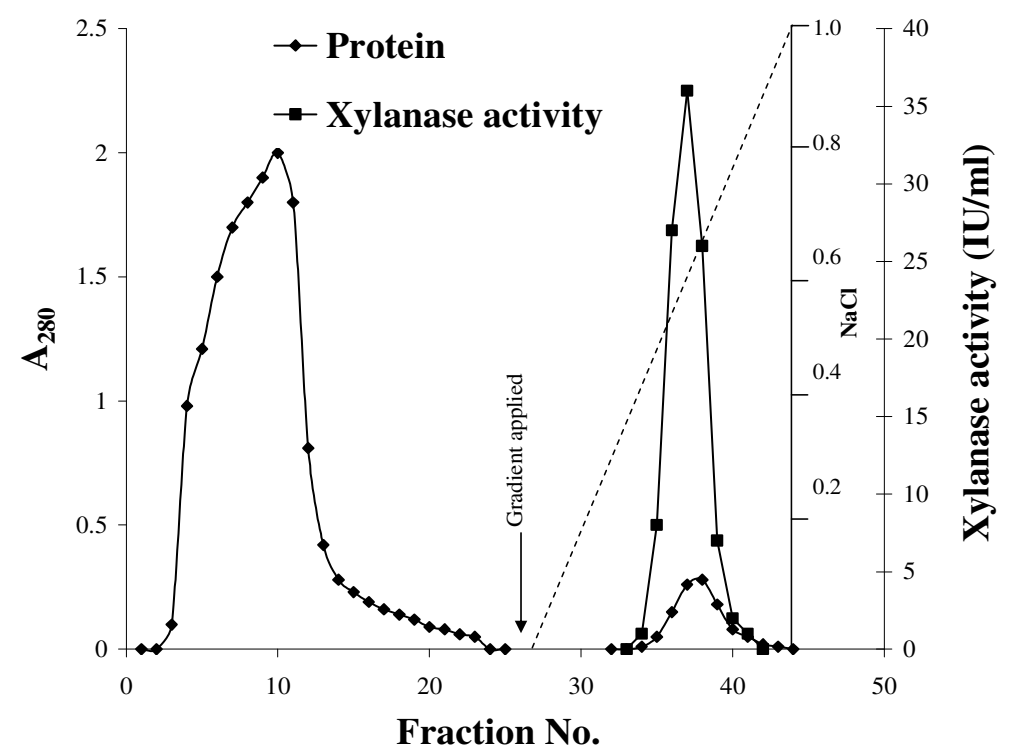

Figure 1. Purification of xylanase by ion-exchange chromatography through CM-Sephadex C-50 column $(20 \times 2.0 \mathrm{~cm})$ preequilibrated with $50 \mathrm{mM}$ sodium phosphate buffer, $\mathrm{pH}$ 6.0. The bound proteins were eluted using a linear gradient of 0-1.0 M $\mathrm{NaCl}$ at a flow rate of $40 \mathrm{ml} / \mathrm{h}$. Fractions of $5 \mathrm{ml}$ each were collected and assayed. 


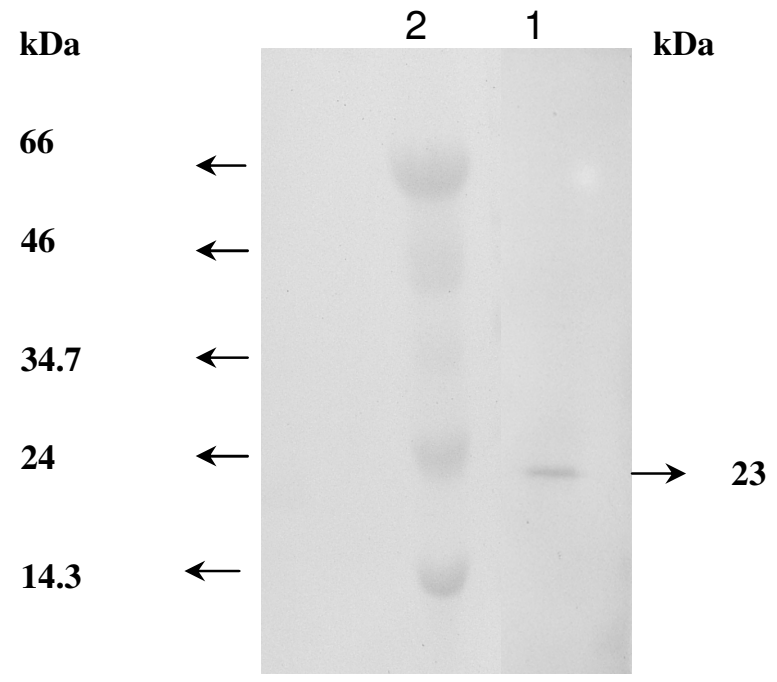

Figure 2. SDS-PAGE analysis of the purified xylanase from Bacillus subtilis ASH. Lane 1: purified xylanase; Lane 2: molecular weight markers viz. lysozyme (14.3 kDa), trypsinogen $(24 \mathrm{kDa})$, pepsin $(34.7 \mathrm{kDa})$, ovalbumin $(46 \mathrm{kDa})$ and BSA (66 kDa). Electrophoresis was performed using 12\% polyacrylamide gel. The gel was stained with coomassie brilliant blue R-250.

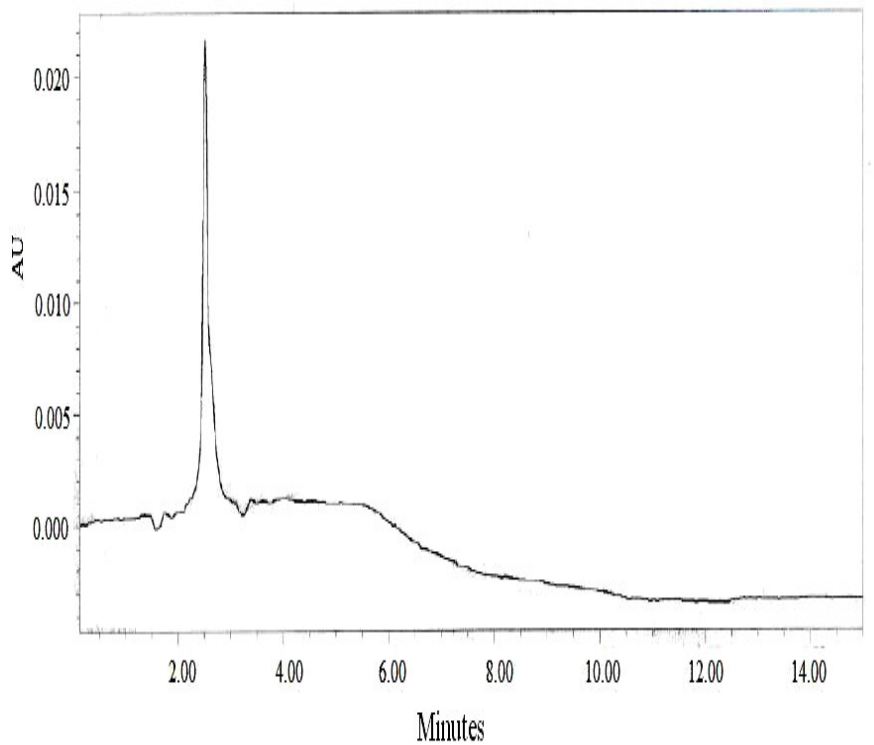

Figure 3. HPLC profile of the purified xylanase from Bacillus subtilis ASH using a reverse phase C-18 column (4.6 x 250 $\mathrm{mm})$. The purified enzyme $(10 \mu \mathrm{l})$ was injected into the loop of column and eluted with acetonitrile-water (70:30) at a flow rate of $0.5 \mathrm{ml} / \mathrm{min}$. A photo-diode array (PDA) detector was set to read the absorbance at $280 \mathrm{~nm}$.

Table 1. Purification of xylanase from Bacillus subtilis ASH. The enzyme was produced in solid state fermentation using wheat bran and the crude extract obtained after $72 \mathrm{~h}$ incubation was subjected to purification.

\begin{tabular}{rccccc}
\hline Purification step & $\begin{array}{c}\text { Total } \\
\text { activity }\end{array}$ & $\begin{array}{c}\text { Total } \\
\text { Protein } \\
\text { (IU) }\end{array}$ & $\begin{array}{c}\text { Specific activity } \\
(\mathrm{mg})\end{array}$ & $\begin{array}{c}\text { Recover } \\
\text { (IU/mg protein) }\end{array}$ & $\begin{array}{c}\text { Purification }(\%) \\
\text { fold }\end{array}$ \\
\hline Crude extract & $\mathbf{4 0 0 0}$ & $\mathbf{3 3 . 0}$ & $\mathbf{1 2 1 . 2}$ & $\mathbf{1 0 0 . 0}$ & $\mathbf{1 . 0}$ \\
CM-Sephadex C-50 & $\mathbf{1 7 2 2}$ & $\mathbf{1 . 3 5}$ & $\mathbf{1 2 7 5 . 5}$ & $\mathbf{4 3 . 0 5}$ & $\mathbf{1 0 . 5}$ \\
\hline
\end{tabular}

One-step chromatographic procedure for purification of xylanase from B. subtilis ASH is rapid and economical which is desirable for its industrial application. Other research groups reported purification of xylanase by employing a combination of two or more different methods including salt fractionation, ion-exchange, gel filtration and hydrophobic interaction chromatography $(1,5,7,16,24,29,35,36)$. The overall purification in the present study using one step was higher than that reported from Bacillus amyloliquefaciens (7) and Bacillus circulans (36) using a multistep sequence of purification. Further, recovery of the purified enzyme from B. subtilis ASH following one step protocol was better than that obtained by using multistep protocol $(1,5,16,24)$. However, grouping of two or more techniques resulted in higher purification fold (1, $5,16,24,35)$ or recovery (7). 


\section{Molecular weight determination}

The purified enzyme showed a single protein band on SDS-PAGE corresponding to a molecular mass of $23 \mathrm{kDa}$ (Fig.

2 ). The purified enzyme eluted as a single peak when applied to Sephadex G-100 column (Fig. 4) with a molecular weight 23 $\mathrm{kDa}$ as calculated from the standard graph (Fig. 5). An identical molecular mass obtained by gel filtration chromatography and SDS-PAGE suggested that the enzyme was a monomer consisting of a single polypeptide chain.

The molecular weight of $B$. subtilis ASH xylanase was identical to the enzyme reported from B. circulans AB16 (10),
Bacillus sp. strain TAR-1 (42), Bacillus licheniformis A99 (1), Arthrobacter sp. (16), Paecilomyces themophila (23) and Streptomyces cyaneus SN32 (33). However, it was higher than $5.5 \mathrm{kDa}$ as observed by Bastawde (4). In contrast, some workers documented a higher molecular weight than that observed in the present study $(5,19,20,38,39)$. Low molecular weight xylanases are preferred for commercial application in paper and pulp industry as they penetrate throughout the pulp fibres more effectively to hydrolyze xylan making the fiber structure more permeable to extraction of lignin by chemicals (21).

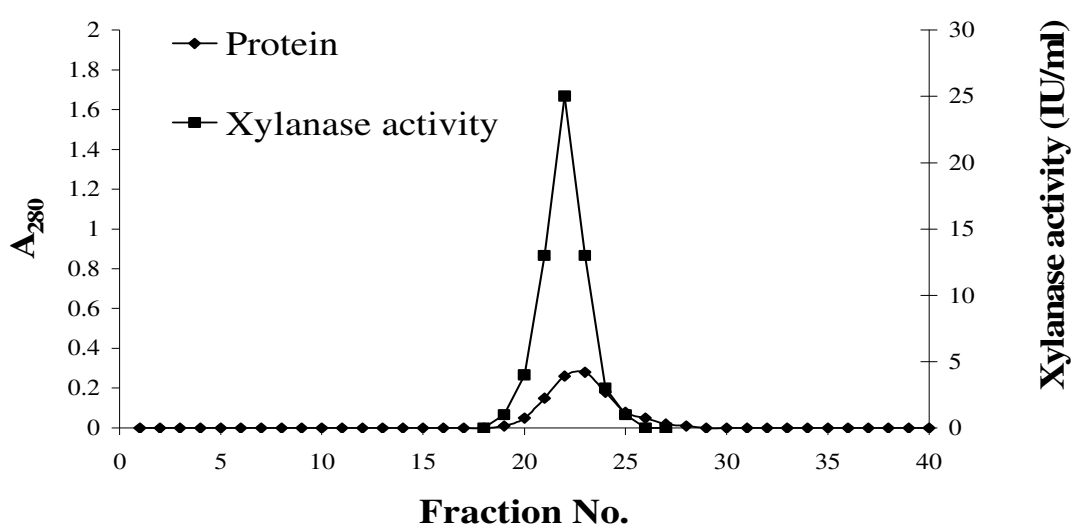

Figure 4. Elution profile of the purified xylanase through Sephadex G-100 column $(90$ x $0.8 \mathrm{~cm})$ eluted with 50 mM sodium phosphate buffer, pH 6.0 at $15 \mathrm{ml} / \mathrm{h}$. Fractions of $3 \mathrm{ml}$ each were collected and analyzed for enzyme activity and protein.

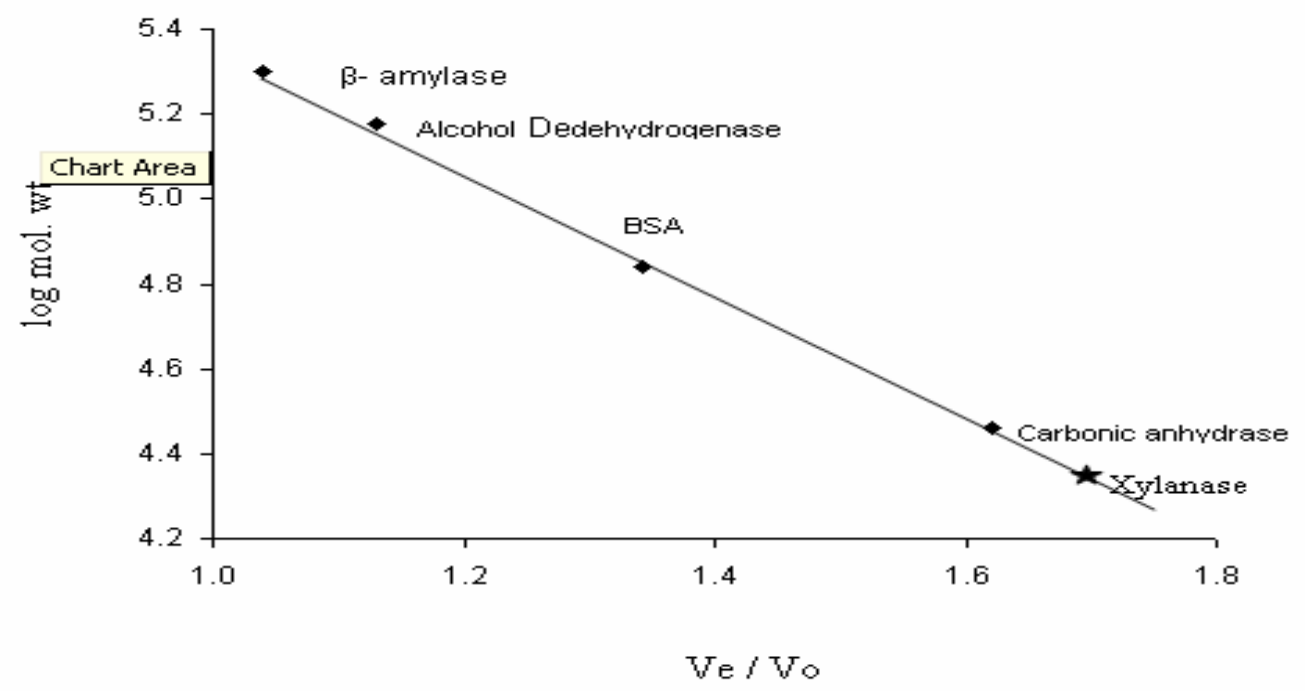

Figure 5. Determination of molecular weight of the purified xylanase from Bacillus subtilis ASH by gel filtration through Sephadex G100 column. The elution volume of the purified enzyme and molecular weight marker proteins viz. carbonic anhydrase (29 kDa), BSA (66 kDa), alcohol dehydrogenase (150 kDa) and $\beta$-amylase (205 kDa) was determined. A graph was plotted between Ve/Vo and log MW. 


\section{Determination of $K_{m}$ and $V_{\text {max }}$}

The activity of the purified xylanase from $B$. subtilis ASH, measured at various concentrations of birch wood xylan (1-15 $\mathrm{mg} / \mathrm{ml}$ ) as substrate, exhibited a rectangular hyperbolic response thus obeying Michaelis-Menton Kinetics. The apparent $\mathrm{K}_{\mathrm{m}}$ and $\mathrm{V}_{\max }$ values obtained from the LineweaverBurk plot (1/v versus $1 /[\mathrm{S}])$ were $3.33 \mathrm{mg} / \mathrm{ml}$ and $100 \mathrm{IU} / \mathrm{ml}$, respectively. These values were comparable to those for xylanases isolated from Bacillus sp. strain 41-1 (31), Bacillus sp NCIM 59 (32), B. circulans Teri-42 (36), Aspergillus niger (29) and Thermomyces lanuginosus (24). However, some xylanases were found to have lower $\mathrm{K}_{\mathrm{m}}$ ranging from 0.025-1.7 $\mathrm{mg} / \mathrm{ml}(8,16,23,38)$.

\section{Effect of temperature on xylanase activity and stability}

Measurement of xylanase activity at different temperatures showed that the activity increased up to $55{ }^{\circ} \mathrm{C}$ and then declined progressively retaining $57 \%$ of the residual activity at $65^{\circ} \mathrm{C}$. The optimum temperature of the purified xylanase from B. subtilis ASH was $55^{\circ} \mathrm{C}$ as the enzyme was most active at this temperature (Fig. 6). Thermostability study of the purified enzyme revealed that it did not lose any activity up to $45^{\circ} \mathrm{C}$. However, it retained $80 \%$ and $51 \%$ of its activity after preincubation at $55^{\circ} \mathrm{C}$ and $60{ }^{\circ} \mathrm{C}$ respectively (Fig. 7). Significant enzyme stability at higher temperatures would be important for its industrial application. Purified xylanases exhibiting optimum temperature in the range of $50-55{ }^{\circ} \mathrm{C}$ have been reported from several Bacillus and Streptomyces sp. (1, 6, 38, 44). However, some xylanases showed higher temperature optima $(5,7,16,18,24)$.

\section{Effect of pH on xylanase activity and stability}

The purified enzyme showed more than $90 \%$ activity in the $\mathrm{pH}$ range 6.5 to 7.5 with maximum at $\mathrm{pH} 7.0$. It was active at alkaline $\mathrm{pH}$ values although, to a lesser extent than at $\mathrm{pH} 7.0$ (Fig. 8). The enzyme retained $80 \%, 28 \%$ and $10 \%$ activity when assayed at $\mathrm{pH}$ 8.0, 9.0 and 10.0, respectively. Maximum $\mathrm{pH}$ stability of the purified xylanase from $B$. subtilis ASH was between $\mathrm{pH}$ 6.0-7.5. On pre-incubation for $10 \mathrm{~min}$ at $\mathrm{pH} 8.0$ and 9.0, the residual enzyme activity was $85 \%$ and $50 \%$, respectively (Fig. 9). A similar $\mathrm{pH}$ optimum was reported for xylanase isolated from Bacillus spp. (7, 18, 30, 36), Staphylococcus sp. (13), Paecilomyces themophila (23) and Thermomyces lanuginosus (24). However, some xylanases exhibited optimum $\mathrm{pH}$ at $6.0(5,33)$. Xylanase from alkalophilic Bacillus sp. strain 41M-1 showed a broad $\mathrm{pH}$ activity profile in the range of $\mathrm{pH} 4.0-11.0$ (31). The $\mathrm{pH}$ stability of the purified thermoalkalophilic xylanase of Bacillus $s p$. ranged from 6.0-10.5 (36). A considerable stability of $B$. subtilis ASH xylanase at alkaline $\mathrm{pH}$ values makes it potentially effective for use in industry.

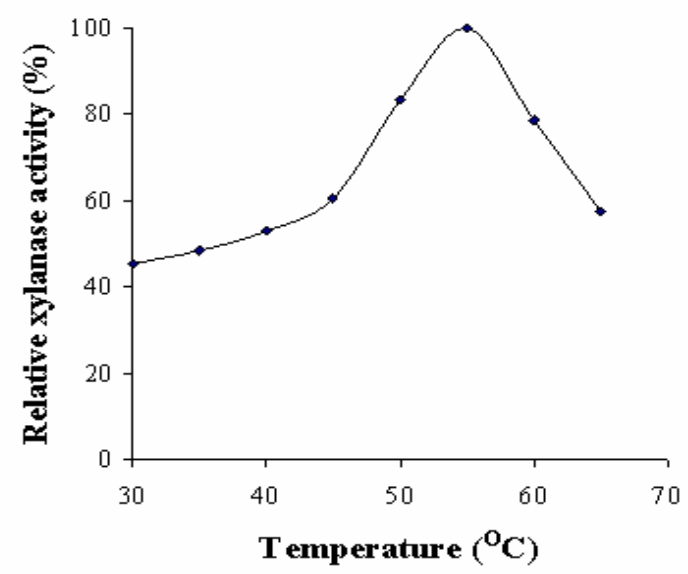

Figure 6. Temperature optima of the purified xylanase from Bacillus subtilis ASH. The enzyme activity was assayed at different temperatures ranging from $30-65{ }^{\circ} \mathrm{C}$ and relative xylanase activity (\%) was calculated.

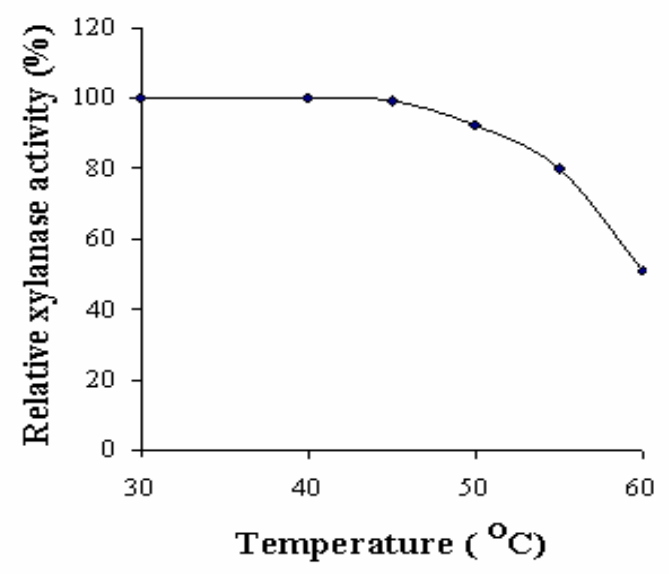

Figure 7. Thermostability of the purified xylanase from Bacillus subtilis ASH. The purified enzyme was pre-incubated at different temperatures $\left(30-60{ }^{\circ} \mathrm{C}\right.$ ) for $10 \mathrm{~min}$ at $\mathrm{pH} 7.0$, quickly chilled and assayed for its residual activity at $55{ }^{\circ} \mathrm{C}$. 


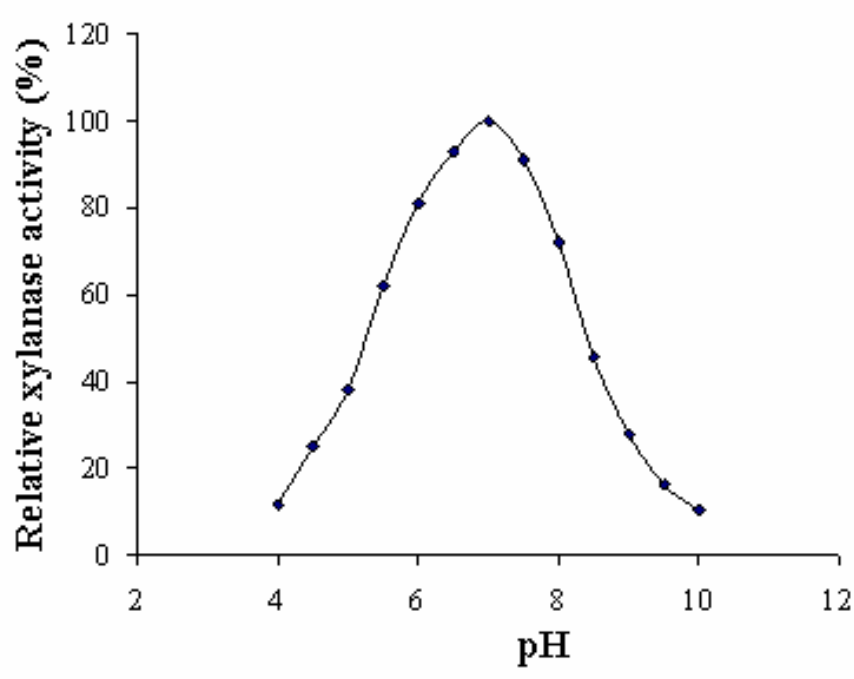

Figure 8. $\mathrm{pH}$ optima of the purified xylanase from Bacillus. subtilis ASH. The enzyme activity was determined at different $\mathrm{pH}$ using citrate $(\mathrm{pH} 4.0-6.0)$, phosphate $(\mathrm{pH}$ 6.0-8.0) and Tris$\mathrm{HCl}(\mathrm{pH} 8.0-10.0)$ buffers.

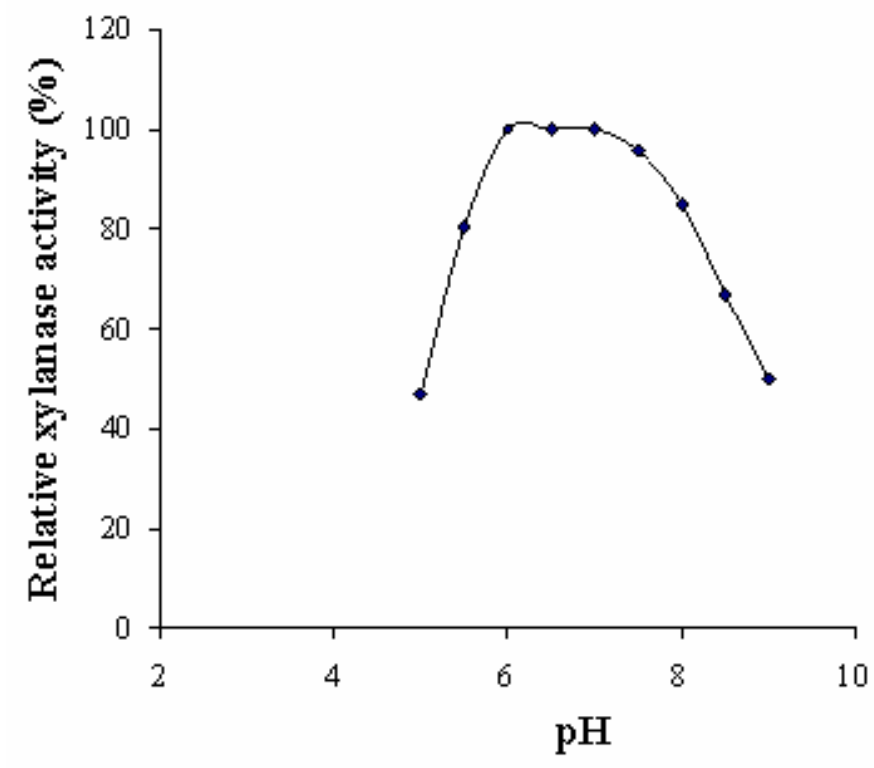

Figure 9. $\mathrm{pH}$ stability of the purified xylanase from Bacillus subtilis ASH. The purified enzyme was pre-incubated with citrate $(\mathrm{pH} 4.0-6.0)$, phosphate $(\mathrm{pH}$ 6.0-8.0) and Tris- $\mathrm{HCl}(\mathrm{pH}$ 8.0-9.0) buffers for $10 \mathrm{~min}$ at room temperature followed by measurement of xylanase activity using sodium phosphate buffer (0.05M, pH 7.0). The residual activity (\%) at each $\mathrm{pH}$ was calculated.

\section{Effect of metal ions on xylanase activity}

Xylanase activity was strongly inhibited by $\mathrm{Hg}^{2+}$ which might be due to its interaction with sulfhydryl groups present on the enzyme. $\mathrm{Cu}^{2+}$ ions were also found to be inhibitory causing $30 \%$ inhibition of enzyme activity (Table 2). Some other metal ions like $\mathrm{Na}^{2+}, \mathrm{K}^{+}, \mathrm{Ca}^{2+}, \mathrm{Ni}^{2+}$ and $\mathrm{Zn}^{2+}$ decreased the enzyme activity but to a very less extent. In contrast, xylanase activity was enhanced in the presence of $\mathrm{Co}^{2+}$ and $\mathrm{Mn}^{2+}$ with $20 \%$ and $85 \%$ increase as compared to the control. $\mathrm{HgCl}_{2}$ has earlier been reported to completely inhibit the activity of xylanase from different sources $(5,16,17,36)$. An increase in xylanase activity in the presence of $\mathrm{MnCl}_{2}$ has also been reported by several workers $(5,13,19)$.

Table 2. Effect of metal ions on the activity of purified xylanase from Bacillus subtilis ASH. The purified enzyme was incubated with various metal salts at $1 \mathrm{~mm}$ concentration for 5 min at room temperature and the xylanase activity was assayed.

\begin{tabular}{lll}
\hline $\begin{array}{c}\text { Metal ion } \\
(\mathbf{1 ~ m M})\end{array}$ & $\begin{array}{c}\text { Xylanase activity } \\
\text { (IU/ml) }\end{array}$ & $\begin{array}{c}\text { Xylanase activity } \\
\text { (\% of control) }\end{array}$ \\
\hline $\mathrm{Control}$ & 85.3 & 100.0 \\
$\mathrm{ZnCl}_{2}$ & 73.6 & 86.3 \\
$\mathrm{CaCl}_{2}$ & 71.6 & 84.0 \\
$\mathrm{HgCl}_{2}$ & 4.9 & 5.7 \\
$\mathrm{NaCl}$ & 75.5 & 88.5 \\
$\mathrm{KCl}$ & 71.7 & 84.1 \\
$\mathrm{FeCl}_{3}$ & 78.7 & 92.3 \\
$\mathrm{MgCl}_{2}$ & 72.1 & 84.5 \\
$\mathrm{CoCl}_{2}$ & 102.4 & 120.0 \\
$\mathrm{CdCl}_{2}$ & 73.5 & 86.2 \\
$\mathrm{NiCl}_{2}$ & 70.5 & 82.6 \\
$\mathrm{CuCl}_{2}$ & 59.6 & 69.9 \\
$\mathrm{MnCl}_{2}$ & 157.8 & 185.0 \\
\hline
\end{tabular}




\section{Determination of shelf life of xylanase}

The purified enzyme did not lose any activity when stored at $4{ }^{\circ} \mathrm{C}$ for six weeks but thereafter, a decline was observed. The enzyme retained $80 \%$ its initial activity after 10 weeks which would be important for its application. On the other hand, at room temperature, the enzyme was completely stable for three weeks but showed $60 \%$ and $50 \%$ residual activity after storage for 7 and 10 weeks, respectively.

To sum up, an extracellular, cellulase-free xylanase has been produced in high titer by $B$. subtilis ASH in solid state fermentation using wheat bran, a cost-effective agro-residue. This enzyme was purified to homogeneity in a single step by cation exchange chromatography on CM-Sephadex C-50. The characteristics of the purified enzyme have been studied. The one-step procedure for xylanase purification reported in the present study is rapid and economical. This protocol together with the characteristics of the purified enzyme such as significant stability at higher temperatures and alkaline $\mathrm{pH}$ make it potentially effective for industrial applications.

\section{ACKNOWLEDGEMENTS}

The authors duly acknowledge the financial assistance received from the Department of Biotechnology, Ministry of Science and Technology, Govt. of India, New Delhi in the form of a research project (No.BT/PR3445/AGR/16/283/2002IV). The first author thanks Kurukshetra University, Kurukshetra for awarding University Research Fellowship.

\section{REFERENCES}

1. Archana, A.; Satyanarayana, T. (2003). Purification and characterization of cellulase-free xylanase of a moderate thermophile Bacillus licheniformis A99. World J. Microbiol. Biotechnol., 19: 53-57.

2. Babu, K.R.; Satyanarayana, T. (1995). $\alpha$-Amylase production by thermophilic Bacillus coagulans in solid-state fermentation. Process Biochem., 30: 305-309.

3. Bakri, Y.; Jawhar, M.; Arabi, M.I.E. (2008). Improvement of xylanase production by Cochliobolus sativus in solid state fermentation. Braz. J. Microbiol., 39: 602-604.

4. Bastawde, K.B. (1992). Xylan structure, microbial xylanases, and their mode of action. World J. Microbiol. Biotechnol., 8: 353-368.
5. Bataillon, M.; Cardinali, A.P.N.; Castillon, N.; Duchiron, F. (2000) Purification and characterization of a moderately thermostable xylanase from Bacillus sp. strain SPS-O. Enzyme Microb. Technol., 26: 187-192.

6. Blanco, A.; Vidal, T.; Colom, J.; Pastor, F.I.J. (1995). Purification and properties of xylanase A from alkali-tolerant Bacillus sp. strain BP-23. Appl. Environ. Microbiol., 61: 4468-4470.

7. Breccia, J.D.; Sineniz, F.; Baigori, M.D.; Castro, G.R.; Hatti, K.R. (1998). Purification and characterization of a thermostable xylanase from Bacillus amyloliquefaciens. Enzyme Microb. Technol., 22: 42-49.

8. Chaudhary, P.; Debunker, D. (1997). Purification and characterization of xylanase from Cellulomonas sp. NCIM 2353. Biotechnol. Appl. Biochem., 25: 127-133.

9. Da Silva, R.; Lago, E.S.; Merheb, C.W.; Macchione, M.M.; Park, Y.K.; Gomes, E. (2005). Production of xylanase and CMCase on solid state fermentation in different residues by Thermoascus aurantiacus miehe. Braz. J. Microbiol., 36: 235-241.

10. Dhillon, A.; Gupta, J.K.; Khanna, S. (2000). Enhanced production, purification and characterization of a novel cellulase poor thermostable, alkali tolerant xylanase from Bacillus circulans $\mathrm{AB}$ 16. Process Biochem., 35: 849-856.

11. Gilbert, H.J.; Hazlewood, G.P. (1993). Bacterial cellulases and xylanases. J. Gen. Microbiol., 139: 187-194.

12. Goyal, M.; Kalra, K.L.; Sareen, V.K.; Soni, G. (2008). Xylanase production with xylan rich lignocellulosic wastes by a local soil isolate of Trichoderma viride. Braz. J. Microbiol., 39: 535-541.

13. Gupta, S.; Bhushan, B.; Hoondal, G.S. (2000). Isolation, purification and characterization of xylanase from Staphylococcus sp. SG-13 and its application in biobleaching of kraft pulp. J. Appl. Microbiol., 88: 325334.

14. Jecu, L. (2000). Solid-state fermentation of agricultural wastes for endoglucanase production. Ind. Crops Prod., 11: 1-5.

15. Kapoor, M.; Beg, Q.K.; Bhushan, B.; Singh, K.; Dadhich, K.S.; Hoondal, G.S. (2001). Application of an alkaline and thermostable polygalacturonase from Bacillus sp. MG-cp-2 in degumming of ramie (Boehmeria nivea) and sunn hemp (Crotalaria juncea) bast fibers. Process Biochem., 36: 803-807.

16. Khandeparker, R.D.S.; Bhosle, N.B. (2006). Isolation, purification and characterization of the xylanase produced by Arthrobacter sp. MTCC 5214 when grown in solid-state fermentation. Enzyme Microb. Technol., 39(4): 732-742.

17. Khanna, S.; Gauri, P. (1993). Regulation, purification and properties of xylanase from Cellulomonas fimi. Enzyme Microb. Technol., 15: 990995.

18. Khasin, A.; Alchanati, I.; Shoham, Y. (1993). Purification and characterization of a thermostable xylanase from Bacillus stearothermophilus T-6. Appl. Environ. Microbiol., 59(6): 1725-1730.

19. Kiddinamoorthy, J.; Anceno, J.A.; Haki, D.G. Rakshit, S.K. (2008). Production, purification and characterization of Bacillus sp. GRE7 
xylanase and its application in eucalyptus Kraft pulp biobleaching. World J. Microbiol. Biotechnol., 24: 605- 612.

20. Ko, C.H.; Chen, W.L.; Tsai, C.H.; Jane, W.N.; Liu, C.C.; Tu, J. (2007). Paenibacillus campinasensis BL11: A wood material-utilizing bacterial strain isolated from black liquor. Bioresour. Technol., 98: 2727-2733.

21. Kuhad, R.C.; Singh, A. (1993). Lignocellulose biotechnology: current and future prospects. Crit. Rev. Biotech., 13: 151-172.

22. Laemmli, U.K. (1970). Cleavage of structural proteins during the assembly of the head of bacteriophage T4. Nature, 227: 680-685.

23. Li, L.; Tian, H.; Cheng, Y.; Jiang, Z.; Yang, S. (2006). Purification and characterization of a thermostable cellulase-free xylanase from the newly isolated Paecilomyces themophila. Enzyme Microb. Technol., 38: 780787.

24. Li, X.T.; Jiang, Z.Q.; Li, L.T.; Yang, Q.S.; Feng, W.Y.; Fan, J.Y.; Kusakabe, I. (2005). Characterization of a cellulase-free, neutral xylanase from Thermomyces lanuginosus CBS 288.54 and its biobleaching effect on wheat straw pulp. Bioresour. Technol., 96: 1370-1379.

25. Lineweaver, H.; Burk, D. (1934). The determination of enzyme dissociation constants. J. Am. Chem. Soc., 56: 658-666.

26. Liu, W.; Zhu, W.; Lu, Y.; Kong, J.; Ma, G. (1998). Production, partial purification and characterization of xylanase from Trichosporon cutaneum SL409. Process Biochem., 33: 331-336.

27. Lowry, O.H.; Rosebrough, N.J.; Farr, A.L.; Randall, R.J. (1951). Protein measurement with Folin phenol reagent. J. Biol. Chem., 193: 265-275.

28. Miller, G.H. (1959). Use of dinitrosalicylic acid reagent for determination of reducing sugar. Anal. Chem., 31: 426-429.

29. Nair, S.G.; Sindhu, R.; Shashidhar, S. (2008). Purification and biochemical characterization of two xylanases from Aspergillus sydowii SBS 45. Appl. Biochem. Biotechnol., 149: 229-243.

30. Nakamura, S.; Nakai, R.; Wakabayashi, K.; Ishiguro, Y.; Aono, R. Horikoshi, K. (1994). Thermophilic alkaline xylanase from newly isolated alkalophilic and thermophilic Bacillus strain TAR-1. Biosci. Biotechnol. Biochem., 58: 78-81.

31. Nakamura, S.; Wakabayashi, K.; Nakai, R.; Aono, R.; Horikoshi, K. (1993). Purification and some properties of an alkaline xylanase from alkaliphilic Bacillus sp. strain 41M-1. Appl. Environ. Microbiol., 59: 2311-2316.

32. Nath, D.; Rao, M. (2001). pH dependent conformational and structural changes of xylanase from an alkalophilic thermophilic Bacillus sp (NCIM 59). Enzyme Microb. Technol., 28: 397-403.

33. Ninawe, S.; Kapoor, M.; Kuhad. R.C. (2007). Purification and characterization of extracellular xylanase from Streptomyces cyaneus SN32. Bioresour. Technol., 99: 1252-1258.

34. Okafor, U.A.; Okochi, V.I.; Onyegeme-okerenta, B.M.; Nwodo-Chinedu, S. (2007). Xylanase production by Aspergillus niger ANL 301 using agro-wastes. African J. Biotechnol., 6(14): 1710-1714.

35. Panbangred, W.; Shinmyo, A.; Kinoshita, S.; Okada, H. (1983). Purification and properties of endoxylanase produced by Bacillus pumilus. Agric. Biol. Chem., 47: 957-963.

36. Qureshy, A.F.; Khan, L.A.; Khanna, S. (2002). Cloning, regulation and purification of cellulase-free xylanase from Bacillus circulans Teri-42. Indian J. Microbiol., 42: 35-41.

37. Sanghi, A.; Garg, N.; Sharma, J.; Kuhar, K.; Kuhad, R.C.; Gupta, V.K. (2007). Optimization of xylanase production using inexpensive agroresidues by alkalophilic Bacillus subtilis ASH in solid-state fermentation. World J. Microbiol. Biotechnol., 24: 633-640.

38. Sa-Pereira, P.; Duarte, J.; Costa-Ferreira, M. (2000). Electroelution as a simple and fast protein purification method: isolation of an extracellular xylanase from Bacillus sp. CCMI 966. Enzyme Microb. Technol., 27: 9599.

39. Sapre, M.P.; Jha, H.; Patil, M.B. (2005). Purification and characterization of a thermoalkalophilic xylanase from Bacillus sp. World J. Microbiol. Biotechnol., 21: 649-654.

40. Srinivasan, M.D.; Rele, M.V. (1999). Microbial xylanases for paper industry. Curr. Sci. 77: 137-142.

41. Sunna, A.; Antranikian, G._(1997). Xylanolytic enzymes from fungi and bacteria. Crit. Rev. Biotechnol., 17: 39-67.

42. Takahashi, H.; Nakai, R.; Nakamura, S. (2000). Purification and partial characterization of a basic xylanase from thermoalkalophilic Bacillus $s p$. strain TAR-1. Biosci. Biotechnol. Biochem., 64(4): 887-890.

43. Viikari, L.; Kantelinen, A.; Sundquist, J.; Linko, M. (1994). Xylanases in bleaching: from an idea to the industry. FEMS Microbiol. Rev., 13: 335350.

44. Virupakshi, K.; Kyu, K.L.; Tanticharoen, M. (2005). Purification and properties of a xylan-binding endoxylanase from alkalophilic Bacillus sp. strain K-1. Appl. Environ. Microbiol., 65: 694-697. 